\title{
Adolescent Hypertension: A Challenge for the Future Danasekaran $R^{1}$, Mani $G^{2}$, Annadurai $K^{3}$
}

\begin{abstract}
:
Hypertension emerges from a complex interplay of genetic, environmental and behavioral factors. Hypertension in the young which is mostly undiagnosed is increasing in prevalence, with much of the increase being fuelled by the increase in obesity among them. Apart from obesity, factors that have an influence on hypertension are hereditary effects, stress, race and diet. It is well established that blood pressure during childhood and adolescence is a predictor of adult blood pressure, which in turn increases mortality from Cardiovascular, Cerebro vascular and other complications, clearly underscores the importance of identification and treatment of hypertension among them.
\end{abstract}

Kevwords: Hypertension; obesity; adolescence; blood pressure; hereditary.

Bangladesh Journal of Medical Science Vol. 15 No. 01 January'16. Page : 5-9

\section{Introduction:}

Hypertension is an iceberg disease with high morbidity \& mortality and is a silent threat to the health of the people both in developed and developing countries. It plays a major role in the development of ischemic heart disease, cerebrovascular disease, cardiac and renal failure. Unlike most of the diseases hypertension mostly goes unnoticed before the development of complications. Around 1 billion people in the world were Hypertensives in the year 2000 and this is expected to increase to 1.56 billion by $2025^{1}$. About $54 \%$ of all stroke and $47 \%$ of all coronary artery disease are attributable to hypertension ${ }^{2}$. Globally, the overall prevalence of raised blood pressure (BP) in adults aged 25 and over was around $40 \%$ in 2008. The prevalence of raised BP was highest in the World Health Organization African Region, where it was $46 \%$ for males and females combined ${ }^{3}$.

Adolescent Hypertension:

Hypertension emerges from a complex interplay of genetic, environmental and behavioural factors. Owing to the hereditary component of hypertension, the disorder is considered to have its origin in the childhood. Children and adolescents with high BP tend to maintain those levels of BP in adulthood ${ }^{4}$.
Apart from progression of hypertension into adult life; there are other complications of childhood and adolescent hypertension. Hypertension in the young is increasing in prevalence, with much of the increase being fuelled by the increase in obesity among them. Worldwide prevalence of Hypertension among adolescents is not known. The prevalence of hypertension among children and adolescents in recently done studies in western countries ranged from $7 \%$ to $19 \%{ }^{5}$.

\section{Classification of Adolescent Hypertension:}

According to the Fourth report on the diagnosis, evaluation and treatment of high blood pressure in children and adolescents by National High Blood Pressure Education Program Working Group ${ }^{6}$ blood pressure is classified as follows,

Table 1. Blood Pressure classification in Children and Adolescents

\begin{tabular}{|c|c|}
\hline $\begin{array}{c}\text { Blood Pressure } \\
\text { Classification }\end{array}$ & $\begin{array}{c}\text { Systolic BP (SBP) or Diastolic } \\
\text { BP (DBP) Percentile }\end{array}$ \\
\hline Normal & $<90^{\text {th }}$ Percentile \\
\hline Prehypertension & $\begin{array}{c}90^{\text {th }}-95^{\text {th }} \\
\mathrm{mmHg} \text { or } \text { if } \mathrm{BP} \text { is }>120 / 80\end{array}$ \\
\hline Hypertension & $>95^{\text {th }}$ Percentile \\
\hline
\end{tabular}

1. Raja Danasekaran,

2. Geetha Mani,

3. Kalaivani Annadurai

Assistant Professors, Department of Community Medicine, Shri Sathya Sai Medical College \& Research Institute, Kancheepuram district, Tamil Nadu, India.

Corresponds to: Dr. Raja Danasekaran, Department of Community Medicine, Shri Sathya Sai Medical College \& Research Institute, Thiruporur-Guduvanchery Main Road, Ammapettai village, Sembakkam post, Chenagalpattu Taluk, Kancheepuram district-603 108. E-mail: mailraja84@gmail.com 


\section{Prevalence of Adolescent Hypertension:}

Global prevalence of the disease is not known due to differences in the definition of high $\mathrm{BP}$ and measurement of BP. Lurbe et al in their study on prevalence of masked hypertension reported $7.6 \%$ of hypertension and $0.8 \%$ of sustained hypertension among 592 youths who attended pediatric clinic in a hospital of university of Valencia ${ }^{7}$. In a cross sectional study conducted among 1041 high school students by Nur $\mathrm{N}$ et al in Sivas province of Turkey has identified $4.4 \%$ of the students were having hypertension ${ }^{8}$. In a cross sectional study among urban Asian Indian adolescents by Goel $\mathrm{R}$ et al. the prevalence of hypertension was found to be $6.4 \%$, of which $2.7 \%$ had isolated systolic, $2 \%$ had isolated diastolic and $1.7 \%$ had both systolic and diastolic hypertension ${ }^{9}$.

\section{Etiology of Hypertension among Adolescents:}

Among pre adolescent children primary or essential hypertension is exceedingly rare. In these age groups secondary hypertension is more common (Table 2).

Among the secondary causes of hypertension renal diseases tops the $\operatorname{list}^{10}$. In adolescents, however, essential hypertension accounts for majority of the cases $(80-90 \%)$. The secondary causes of hypertension are comparable to the list of causes in younger children. Primary hypertension in adolescents is mostly characterized by isolated systolic hypertension. On the other hand diastolic hypertension most often accompanies secondary causes of hypertension ${ }^{11}$.

Factors influencing Hypertension among

\section{Adolescents:}

\section{a) Obesity and Hypertension}

The prevalence of obesity in the children and adolescents has increased markedly in the last two decades. Primary hypertension in the adolescents is becoming increasingly common in association with obesity. Moore WE et al. in their study healthy Kids Project reported 28\% of overweight among 769 students from Anadarco student population. They found that BMI more than $95^{\text {th }}$ percentile

Table 2. Estimated Causes of Hypertension in Children and Adolescents

\begin{tabular}{|l|l|l|}
\hline Type & Children & Adolescents \\
\hline Primary / Essential & $\mathbf{1 5 - 3 0 \%}$ & $\mathbf{8 5 - 9 5 \%}$ \\
\hline Secondary Hypertension & $\mathbf{7 0 - 8 5 \%}$ & $\mathbf{5 - 1 5 \%}$ \\
Renal parenchymal & $60-70 \%$ & \\
Renovascular & $5-10 \%$ & \\
Endocrine & $3-5 \%$ & \\
Aortic coarctation & $10-20 \%$ & \\
\hline
\end{tabular}

was strongly associated with elevated BP (RR-3.8; 95\% CI:2.6-5.4) ${ }^{12}$. Paradis G et al. found that BMI was associated with SBP and DBP consistently in all the ages and both the genders. BMI was 4-6 kg/ $\mathrm{m}^{2}$ higher among those with $\mathrm{SBP}>95^{\text {th }}$ percentile ${ }^{13}$. In a study conducted in China by $\mathrm{He} \mathrm{Q}$ et al. hypertension was seen in $19.4 \%$ of obese children and $7 \%$ in non obese children with $\mathrm{P}<0.0001^{14}$. Burgos et al. conducted a study among 1666 school students in Brazil and found that $26.7 \%$ of them were overweight or obese and $35.9 \%$ had body fat percentage moderately high. Hypertension was prevalent among $12.1 \%$ of students and there was a significant correlation with BMI $(\mathrm{P}<0.05)^{15}$.

\section{a) Family History and Hypertension}

Recently published studies have demonstrated that large numbers of adolescents with essential hypertension have a positive family history of hypertension in a parent. Falkner $\mathrm{F}$ et al. followed up adolescents with BP between 90 to $95^{\text {th }}$ percentile. They found that many of them developed hypertension and those who developed hypertension had a strong family history of Hypertension ${ }^{16}$. A study done in Punjab among 2560 school children by Verma $\mathrm{M}$ et al. has reported that family history of hypertension was significantly associated with elevated blood pressure $(\mathrm{P}<0.01){ }^{17}$. Khan MI et al. in their study on hypertension and its risk factors among adolescent boys reported that family history of hypertension and hypertension among boys were having significant association $(\mathrm{P}<0.001)^{18}$.

\section{b) Diet Pattern and Hypertension}

Role of diet in adolescent hypertension is mostly restricted to sodium intake. Role of calcium and potassium in adolescent hypertension is being explored. Soudarssanane $\mathrm{MB}$ et al has also reported that there was no significant association between diet (vegetarian or non vegetarian) and hypertension ${ }^{19}$. In a meta analysis done by $\mathrm{He}$ FJ and MacGregor GA on the effect of salt on $\mathrm{BP}$ in children, it was found that reduction in salt intake by $42 \%$ resulted in significant reductions in blood pressure: systolic-1.17 $\mathrm{mmHg}$ (95\% CI: -1.78 to- $0.56 \mathrm{mmHg} ; \mathrm{P}<0.001)$; diastolic-1.29 mmHg (95\% CI: -1.94 to- $0.65 \mathrm{mmHg} ; \mathrm{P}<0.0001){ }^{20}$

c) Physical Activity and Hypertension Parker ED et al. in their CARDIA study done among 3993 participants on physical activity and incident hypertension on 15 years follow up reported 634 cases of incident 
hypertension. Those with more physical activity had a less risk of incident hypertension than the less physical activity group (Hazard rate ratio $=0.83$; 95\% CI: 0.73-0.93) ${ }^{21}$.

\section{Consequences of Adolescent Hypertension:}

The most important consequence of elevated BP among children and adolescents is that it predicts the development of adult hypertension. The long term sequelae of adult hypertension such as myocardial infarction and stroke do not occur in children. But it has been proved that persistent elevation of BP in children and adolescents can produce other target organ damages such as left ventricular hypertrophy, etc.

a) Hypertension during adulthood (Tracking of BP) It is increasingly clear that adult hypertension have their origin in childhood itself. "Tracking" is persistence of rank order of BP from childhood to adult stage. Many studies have been done to support this phenomenon. In the Bogalusa cohort, $40 \%$ of those with systolic BP and $37 \%$ of those with diastolic BP above the 80th percentile at baseline continued to have BP above the 80th percentile 15 years later ${ }^{22}$. Zinner $\mathrm{SH}$ et al found a significant relation between $\mathrm{BP}$ readings taken initially and follow up reading taken after 4 years. $(p<0.001$ for SBP and $0.14, p=0.001$ for DBP). This data proves that stratification of $\mathrm{BP}$ into peer groups occurs in childhood itself ${ }^{23}$.

b) Increased Cardiovascular Disease in Adulthood As of now there are no clear data on relationship between hypertension during young age and cardio vascular morbidity and mortality in adult life. But studies have shown that BP and cardio vascular risk factors in childhood predict the subsequent presence of Carotid intima-media thickness and arterial stiffness, both of which are accepted markers of atherosclerosis ${ }^{10}$. In the Cardiovascular Risk in young Finns study Juonala $\mathrm{M}$ et al. studied the relationship between childhood BP and endothelial dependent brachial flow mediated dilation in adulthood. They reported an inverse relationship between SBP among male adolescents and adulthood flow mediated dilation ${ }^{24}$. In addition studies have demonstrated that children with hypertension are at increased risk of developing metabolic syndrome during adulthood which is an important predictor of cardiovascular morbidity.

Hypertensive Target Organ Damage in Adolescents: a) Left ventricular hypertrophy $(\mathrm{LVH})$

Among the hypertensive children and adolescents the prevalence of $\mathrm{LVH}$ was found to be between
$10-38 \%$ in various studies. This difference occurs due to variation in echo cardio graphic protocol. Sorof $\mathrm{M} \mathrm{J}$ et al. in their comparative study between hypertensive children identified by school based screening and referred cases found that the prevalence of LVH was $37 \%$ among them. Referral subjects had more left ventricular mass index ${ }^{25}$. McNiece K L et al. found that among hypertensive subjects those with stage 2 hypertension have increased odds for LVH. And the risk for LVH was similar among subjects with stage 1 and masked hypertension whereas the risk was same for those with white coat hypertension and normal subjects ${ }^{26}$. b) Carotid intimal thickening

Atherosclerosis begins in childhood and the common carotid artery intima media thickness is a marker of pre clinical atherosclerosis. Carotid intima-media thickness has become a marker of hypertensive vascular damage. In a prospective cohort study conducted by Raitakari OT et al. 2229 participants were examined during young age (3-18 yrs) and re examined 21 years later. Intimal medial thickness has showed significant association with childhood SBP $(\mathrm{P}<0.001)$, BMI $(\mathrm{P}=0.007)$ and LDL cholesterol $^{27}$. Lande MB et al. in their matched case control study found that the median carotid intima media thickness in hypertensives was greater than controls $(0.67 \mathrm{vs} 0.63 \mathrm{~mm} ; \mathrm{P}=0.045)^{28}$.

\section{c) Impaired cognitive function}

Recently, impaired cognitive function has been described as one of the target organ damage due to hypertension in the children and adolescents. This finding requires confirmation, but adds value to the recommendation of starting anti hypertensive therapy in children with persistently elevated BP. Lande MB et al. compared the cognitive scores of children with elevated BP and normal BP. They found that children with elevated SBP had lower scores for digit span $(\mathrm{p}=0.01)$, block design $(\mathrm{p}=0.03)$ and mathematics $(\mathrm{p}=0.01)$. Children with elevated DBP had lower scores on block design $(\mathrm{p}=0.01)^{29}$.

\section{d) Retinal artery narrowing}

In a population based study conducted in two countries- Australia and Singapore involving 1952 students by Mitchell $\mathrm{P}$ et al. found that children in the higher quartiles of BP were having narrow retinal arterioles than those with normal BP. They reported that for every $10 \mathrm{mmHg}$ increase in SBP there was narrowing of retinal arterioles by $2.08 \mu \mathrm{m}^{30}$.

Management of Adolescent Hypertension: 
The management of hypertension among children and adolescents is largely empirical in contrast to management of hypertension in adults, which is guided by many number of clinical trials. The decision as to whether a child to be started on drug therapy or not should be individualized ${ }^{31}$. Treatment of hypertension should start with non pharmacological measures. Although the magnitude of change in BP may be modest with the measures like weight loss, dietary changes and regular exercise, all of them have shown to reduce BP in adolescents successfully.

Accepted indications for usage of anti hypertensives for treating hypertension in children and adolescents include the following: a) symptomatic hypertension; b) secondary hypertension; c) Type 1 or 2 diabetes; d) Hypertensive target organ damage or e) persistent hypertension despite of non pharmacologic measures. Pharmacologic reduction of $\mathrm{BP}$ in hypertensive children who fall into the above categories is likely to result in health benefits. Other indications for starting drug therapy have been proposed. For example, it is suggested that anti hypertensive therapy is initiated if the child has hyperlipidemia ${ }^{6}$. The anti hypertensives commonly used include Angiotensin converting enzyme inhibitors, Angiotensin Receptor Blockers, $\alpha$ and $\beta$ adrenergic antagonists and Calcium channel blockers31.

The following table shows the classification of blood pressure among adolescents, its evaluation, life style changes for each category and also the pharmacological treatment. (Table 3)

Table 3. Classification and Management of Hypertension in Adolescents ${ }^{10}$

\begin{tabular}{|l|l|l|l|l|}
\hline Classification & $\begin{array}{l}\text { SBP or DBP } \\
\text { percentile }\end{array}$ & $\begin{array}{l}\text { Frequency of } \\
\text { measurement }\end{array}$ & $\begin{array}{l}\text { Therapeutic Lifestyle } \\
\text { changes }\end{array}$ & $\begin{array}{l}\text { Pharmacologic } \\
\text { Therapy }\end{array}$ \\
\hline Normal & $\begin{array}{l}<90^{\text {th }} \\
\text { percentile }\end{array}$ & $\begin{array}{l}\text { Next scheduled } \\
\text { examination }\end{array}$ & $\begin{array}{l}\text { Encourage healthy diet, } \\
\text { physical activity }\end{array}$ & - \\
\hline $\begin{array}{l}\text { Pre } \\
\text { hypertension }\end{array}$ & $\begin{array}{l}90-95^{\text {th }} \\
\text { percentile } \\
\text { or }>120 / 80\end{array}$ & Recheck after 6 months & $\begin{array}{l}\text { Counsel for weight } \\
\text { management, introduce } \\
\text { physical activity and } \\
\text { diet management }\end{array}$ & $\begin{array}{l}\text { Do not start therapy } \\
\text { unless compelling } \\
\text { indications like CKD, } \\
\text { diabetes, heart failure, } \\
\text { LVH exist }\end{array}$ \\
\hline Hypertension & $\begin{array}{l}\text { L5 th } \\
\text { percentile }\end{array}$ & $\begin{array}{l}\text { Recheck in 1-2 weeks; if } \\
\text { persistently elevated in } \\
2 \text { additional occasions, } \\
\text { evaluate or refer within 1 } \\
\text { month }\end{array}$ & $\begin{array}{l}\text { Counsel for weight } \\
\text { management, introduce } \\
\text { physical activity and } \\
\text { diet management }\end{array}$ & $\begin{array}{l}\text { Initiate therapy } \\
\text { or if compelling } \\
\text { indications as above }\end{array}$ \\
\hline
\end{tabular}

\section{Conclusion:}

As the symptoms of childhood and adolescent hypertension are largely nonspecific, most children with hypertension are likely to be undiagnosed. But there are ample evidences proving the development of hypertensive end organ damage in hypertensive children and there are data suggesting hypertension in young may have adverse cardiovascular effects in adulthood. To conclude, blood pressure to be monitored routinely even among adolescents and those who are identified as having high blood pressure should be treated early in order to avoid progression of the disease, which may prove to be a serious health challenge in the future.

\section{References:}

1. Kearney PM, Whelton M, Reynolds K, Muntner P, Whelton PK, He J. Global burden of hypertension: analysis of worldwide data. Lancet 2005;365:217-23. http://dx.doi.org/10.1016/S0140-6736(05)70151-3

2. Patel V, Chatterji S, Chisholm D, Ebrahim S, Gopalakrishna G, Mathers C, Mohan V, Prabhakaran D, Ravindran RD, Reddy KS. Chronic diseases and injuries in India. Lancet 2011;377:413-28. http://dx.doi.org/10.1016/S0140-6736(10)61188-9

3. World Health Organization. The World Health Report 2002:
Risks to Health 2002.Geneva: World Health Organization.

4. Nelson MJ, Ragland DR, Syme SL. Longitudinal prediction of adult blood pressure from juvenile blood pressure levels. Am J Epidemiol 1992;136:633 - 45 .

5. Abolfotouh MA, Sallam SA, Mohammed MS, Loutfy AA, and Hasab AA. Prevalence of Elevated Blood Pressure and Association with Obesity in Egyptian School Adolescents, International Journal of Hypertension; vol. 2011, Article ID 952537:8 pages, 2011. doi:10.4061/2011/952537. http://dx.doi.org/10.4061/2011/952537 
6. National High Blood Pressure Education Program Working Group. The Fourth report on the diagnosis, evaluation and treatment of high blood pressure in children and adolescents. Pediatrics 2004;114:555-76. http://dx.doi.org/10.1542/peds.114.2.S2.555

7. Lurbe E, Torro I, Alvarez V, Nawrot T, Paya R, Redon J. Prevalence, Persistence, and Clinical Significance of Masked Hypertension in Youth. Hypertension 2005;45;493-498. http://dx.doi.org/10.1161/01.HYP.0000160320.39303.ab

8. Nur N, Çetinkaya S, Yilmaz A, Ayvaz A, Bulut MO and Sumer H.Prevalence of Hypertension among High School Students in a Middle Anatolian Province of Turkey. J Health Popul Nutr 2008;26(1):88-94.

9. Goel R, Misra A, Agarwal SK, Vikram N, Correlates of hypertension among urban Asian Indian adolescents. Arch Dis Child 2010;95:992-997. http://dx.doi.org/10.1136/adc.2009.162347

10. Kaplan NM, Victor RG, Flynn T. Kaplan's clinical hypertension, 10th edition. Philadelphia; Lippincott Williams \& Wilkins:430-454.

11. Flynn JT, Alderman MH. Characteristics of children with primary hypertension seen at a referral center. Pediatr Nephrol. 2005 Jul;20(7):961-6. http://dx.doi.org/10.1007/s00467-005-1855-3

12. Moore WE, Stephens A, Wilson T, Wilson W, Eichner JE. Body mass index and blood pressure screening in a rural public school system: the Healthy Kids Project. Prev Chronic Dis [serial online] 2006 Oct [date cited]. Available from: http://www.cdc.gov/pcd/issues/2006/oct/05_0236.htm

13. Paradis G, Lambert M, Loughlin JO, Lavallée C, Aubin J, Delvin E, Lévy E and Hanley JA. Blood Pressure and Adiposity in Children andAdolescents. Circulation 2004;110:1832-1838. http://dx.doi.org/10.1161/01.CIR.0000143100.31752.B7

14. He Q, Ding ZY, Fong DYT, Karlberg J. Blood pressure is associated with body mass index in both normal and obese children. Hypertension 2000;36:165-170. http://dx.doi.org/10.1161/01.HYP.36.2.165

15. Burgos MS, Reuter CP, Burgos LT, Pohl HH, Pauli LTS, Horta JA, Reckziegel MB, Franke SIR, Pra D, Camargo MD. Comparison Analysis of Blood Pressure, Obesity and Cardiorespiratory Fitness in Schoolchildren. Arq Bras Cardiol 2010;94(6):739-744.

16. Falkner B, Kushner H, Onesti G and Angelakos ET. Cardiovascular characteristics in adolescents who develop essential hypertension. Hypertension 1981;3;521-52. http://dx.doi.org/10.1161/01.HYP.3.5.521

17. Verma M, Chhatwal J, George SM. Biophysical profile of blood pressure in schoolchildren. Indian Paediatrics. 1995;32:749-754.

18. Khan MI, Lala MK, Patil R, Mathur HN, Chauhan NT. A study of the risk factors and the prevalence of hypertension in the adolescent school boys of Ahmedabad city. Journal of clinical and diagnostic research. 2010;4:3348-3354.

19. Soudarssanane MB, Karthigeyan M, Stephen S, Sahai A. Key predictors of high blood pressure and hypertension among adolescents: a simple prescription for prevention. Ind J Community Med 2006;31:164-9.
20. He FJ and MacGregor GA. Importance of Salt in Determining Blood Pressure in Children: Meta-Analysis of Controlled Trials. Hypertension 2006;48;861-869. http://dx.doi.org/10.1161/01.HYP.0000245672.27270.4a

21. Parker ED, Schmitz KH, Jacobs DR, Dengel DR, and Schreiner PJ, Physical Activity in Young Adults and Incident Hypertension over 15 Years ofFollow-Up: TheCARDIAStudy. AmericanJournalofPublicHealth2007(April);97(4):703-709. http://dx.doi.org/10.2105/AJPH.2004.055889

22. Bao W, Threefoot SA, Srinivasan SR, Berenson GS. Essential hypertension predicted by tracking of elevated blood pressurefrom childhood toadulthood:TheBogalusaheartstudy. American Journal of Hypertension 1995 (July);8(7):657-665. http://dx.doi.org/10.1016/0895-7061(95)00116-7

23. Zinner SH, Martin LF, Sacks F, Rosner B And Kass EH. A Longitudinal Study of Blood Pressure in Childhood. American Journal of Epidemiology;100(6):437-442.

24. Juonala M, Viikari JS, Rönnemaa $\mathrm{T}$, et al. Elevated blood pressure in adolescent boys predicts endothelial dysfunction: the cardiovascular risk in young Finns study. Hypertension 2006;48: 424-430. http://dx.doi.org/10.1161/01.HYP.0000237666.78217.47

25. Sorof JM, Turner J, Martin DS, Garcia K, Garami Z, Alexandrov AV, Wan F and Portman RJ. Cardiovascular Risk Factors and Sequelae in Hypertensive Children Identified by Referral versus School-Based Screening. Hypertension 2004;43:214-218. http://dx.doi.org/10.1161/01.HYP.0000114696.96318.4e

26. McNiece KL, Malhotra MG, Samuels J, Bell C, Garcia $\mathrm{K}$, et al. Left Ventricular Hypertrophy in Hypertensive Adolescents: Analysis of Risk by 2004 National High Blood Pressure Education Program Working Group Staging Criteria. Hypertension 2007;50;392-395. h t t p : / / d x. d o i . o r g / 10 . $11161 /$ HYPERTENSIONAHA.107.092197

27. Raitakari OT, Juonala M, Kahonen M, Taittonen L, Laitinen T, et.al. Cardiovascular Risk Factors in Childhood and Carotid Artery Intima-Media Thickness in AdulthoodThe Cardiovascular Risk in Young Finns Study. JAMA, November 5, 2003;290(17):2277-2283.

28. Lande MB, Carson NL, Roy J and Meagher CC. Effects of Childhood Primary Hypertension on Carotid Intima Media Thickness: A Matched Controlled Study. Hypertension 2006;48:40-44. http://dx.doi.org/10.1161/01.HYP.0000227029.10536.e8

29. Lande MB, Kaczorowski JM, Auinger P, Schwartz GJ. Elevated blood pressure and decreased cognitivefunction among school-age children and adolescents in the United States. Journal of Pediatrics;143( 6):720-724.

30. Mitchell P, Ning Cheung, Kristin de Haseth, Taylor B, Rochtchina E, Islam FMA, Wang JJ, Saw SM, Wong TY. Blood Pressure and Retinal Arteriolar Narrowing in Children. Hypertension 2007;49:1156-1162. h t $\mathrm{t} \mathrm{p}$ : / / d x. d o i . o r g / 10 . $11161 /$ HYPERTENSIONAHA.106.085910

31. Lip GYH, Hall JE. Comprehensive Hypertension. 1st edition. Philadelphia; Mosby Elsevier, 2007:641-657. 